\title{
Estimation Method of the State of 6-10 kV Distribution Network
}

\author{
Saidjon Sh. Tavarov ${ }^{*}$, Aleksandr I. Sidorov ${ }^{1}$, Rustam G. Valeev ${ }^{2}$, Ekatirina V. Zykina ${ }^{1}$ \\ ${ }^{1}$ Department of "Life Safety", South-Ural State University (National Research University), Lenin Avenue, 76, Chelyabinsk \\ 454080, Russia \\ ${ }^{2}$ Department of Power Stations, Grids, and Electric Power Systems, South-Ural State University (national research university), \\ Lenin Avenue, 76, Chelyabinsk 454080, Russia
}

Corresponding Author Email: tabarovsaid@mail.ru

https://doi.org/10.18280/ejee.230202

Received: 1 August 2020

Accepted: 10 March 2021

\section{Keywords:}

electrical distribution networks, reliability indicators

\begin{abstract}
The article analyzes the state of the elements of 6-10 kV distribution electrical networks in Dushanbe, showing the excess of reliability and efficiency indicators of the considered electrical networks from the permissible $10 \%$ values. For the first time, the factors influencing the reliability indicators of $6-10 \mathrm{kV}$ electrical distribution network elements in Dushanbe were identified and a mathematical model of networks for determining the state of 6-10 kV electrical distribution network elements in Dushanbe was proposed. On the basis of them, an algorithm for monitoring the state of the elements of $6-10 \mathrm{kV}$ electrical distribution networks in Dushanbe is proposed, which makes it possible to evaluate the efficiency of 6-10 kV distribution electrical networks in terms of undersupply of electricity $-\Delta \mathrm{W}$.
\end{abstract}

\section{INTRODUCTION}

The state of the reliability indicators of the elements of power supply systems can be influenced by many factors, most of which are of a random nature. According to the references [1-4], the quality indicators of reliability are not suitable for engineering purposes.

For practical calculations in power supply systems, quantitative characteristics of reliability are used, based on the methods of probability theory and mathematical statistics. The advantages and disadvantages of a number of these methods are discussed in detail in $[1,3,4]$.

To assess the reliability indicators of the elements of the 6$10 \mathrm{kV}$ distribution electric networks, it is necessary to use a quantitative assessment of reliability [5-7]. According to literatures $[1,3,4]$, the main indicators of the reliability of the elements of the power supply circuit for a quantitative assessment are:

- Intensity and frequency of failures;

- The average recovery time.

The efficiency of the electrical distribution network, as a rule, is assessed according to reliability criteria, the difference between the supplied and received electricity, operating modes and execution schemes. In turn, the reliability of elements of electrical networks, including distribution, is assessed by reliability indicators. According to Grishkevich [1], all elements of electrical networks are divided into nonrecoverable and recoverable after damage. Non-recoverable elements of electrical networks include a number of elements given in literatures [1-3], but we will focus on the reliability indicators of recoverable elements, which include most of the elements of the distribution network [8-12], including transformers (TP), air (OHL) and cable lines (CL).

The quantitative assessment of the reliability indicators of the restored elements of the distribution electric network is estimated according to the following indicators $[1,2]$ : the flow of failures $(\omega)$, the recovery time of damaged elements $\left(t_{\text {renovation }}\right)$ and the shortage of electricity $(\Delta \mathrm{W})$ associated with an interruption in the power supply. These indicators allow us to quantify the degree of reliability of the elements of the electrical distribution network and to propose, based on a certain mathematical model, measures to increase them [2].

\section{RESEARCH METHOD}

In the Republic of Tajikistan, investigation and recording of technological violations is carried out in accordance with the current document GD 34.20.801-90 Instructions for the investigation and recording of technological violations in the operation of power plants, networks and energy systems.

In the regional and city electrical networks of the Republic of Tajikistan, including in Dushanbe, the operational dispatch service is engaged in the collection, analysis and processing of information.

The collection of information is carried out as follows.

After receiving data via radio communication from the substation duty officer supplying the section that was deenergized, or from the consumers themselves to the duty officer of the operational dispatch service, after recording in the logbook the time of receiving information by radio communication, information is transmitted to cable and overhead line services, as well as to the substation service about emergency shutdown of one or another section with the appropriate dispatching name, which provide an operational field team to identify the reasons for the shutdown and eliminate them.

After receiving information by the above-mentioned services, a team is formed by the chief or his deputy. This team, arriving at the place of damage, determines the cause of the 
damage and transmits information either by mobile communication or by radio communication to the duty officer of the operational dispatch service. After the operator on duty of the operational dispatching service has agreed with the duty officer of the substation about operational switching with simultaneous recording in the log book, the arrived service teams are given permission to arrange the causes of emergency outages.

After the completion of the work by the operational field team, the person responsible for the work contacts the duty officer of the operational dispatch service and informs him about the elimination of the causes of emergency shutdowns. The duty officer of the operational dispatch service records the time in the logbook and contacts the duty officer of the substation supplying this section and gives an indication to return the circuit to its original position and re-enable the cell of the emergency disconnected section. The substation attendant, having fulfilled all the installed commands, re-turns on the emergency disconnected cell. After successful switching on, it informs the operator on duty of the operational dispatch service about the successful switching on of the cell via the radio channel. The duty officer of the operational dispatching service records the time of switching on the cell in the log book and informs the operational field brigade of the successful switching on.

About this incident, in addition to being recorded in the logbook by the duty officer of the operational dispatch service, the duty officer informs the head of the operational dispatch service about the elimination of the damage.

Every day, information on the number of emergency shutdowns without thorough analysis and processing of information with the identification of the main reasons that led to the emergency shutdown is transmitted to the management of the organization. Semi-annual and annual reports are closed in the same form. This situation with the analysis and processing of information to identify the causes of emergency shutdowns, in our opinion, is due to low-quality information transmitted by the operational field team. This is due to the following.

After the arrival of the mobile team and a visual inspection of the place of damage, a general picture of what happened is given, without identifying the reasons that led to this damage. Consequently, the duty officer of the operational dispatch service records the information that was transmitted to him in the log book. We believe that the quality of the transmitted information is affected by a number of points:

(1) Due to the lack of understanding of the processes occurring in electrical networks and leading to one or damage, any hidden damage is brought to the general types of damage. This is due, first of all, to the fact that after analyzing any such damage at meetings of the services, such accidents are qualified as general damage without a thorough analysis and, therefore, the working personnel, service foremen do not pay due attention when establishing the main causes of damage;

(2) Lack of recommendations of the operational field team, which would provide a list of possible causes of damage to an element of the distribution network.

Due to ineffective analysis and processing of information, often after the re-inclusion of damaged areas, repeated emergency shutdowns occur either in the same zone or in the same areas. This leads to a number of negative consequences, such as:

(1) Rapid wears of newly installed elements of urban electrical networks;
(2) Large undersupply and high losses of electricity, which negatively affects the economic condition of city and regional power grids.

Thus, on the basis of the above, for the high-quality collection, processing, and analysis of information in order to identify the main and additional factors affecting damage and emergency shutdowns, the most effective and affordable method for collecting, processing and analyzing the information received about damage to individual elements of distribution electrical networks is proposed Dushanbe.

We believe that this technique will reveal the factors leading to hidden damage, which can be effectively used for the implementation of the Smart Grid system in Dushanbe.

\subsection{Description of the proposed methodology for collecting, processing and analyzing information}

1. All services involved in maintenance, repair of elements of 6-10 kV distribution networks in Dushanbe must be provided with forms, which indicate the possible causes of damage, depending on the type of damaged element of a particular 6-10 kV distribution network.

Examples of forms of technical (technological) causes of violations leading to damage to an element of a $6-10 \mathrm{kV}$ distribution network are given in Tables 1-3.

2. After completing the work to eliminate the damage and restore the power supply, either on the same day or the next, it is necessary to submit one copy of the form of technical (technological) causes of violations to the operational dispatch service and one copy to the reliability and safety service.

Table 1. Form of technical (technological) causes of violations for cable lines with a voltage of $6-10 \mathrm{kV}$

\begin{tabular}{|c|c|c|c|}
\hline Reasons for violation & Yes & No & $\begin{array}{c}\text { Quantity } \\
\text { pes. }\end{array}$ \\
\hline $\begin{array}{c}\text { Violation of the structure of the } \\
\text { material of the installation, its part or } \\
\text { assembly } \\
\text { Violation of welding, soldering } \\
\text { Loss of mechanical connection } \\
\text { Thermal damage, overheating, burnout } \\
\text { Electric arc damage } \\
\text { Violation of electrical insulation } \\
\text { Loss of electrical contact } \\
\text { Mechanical destruction } \\
\text { No reasons identified }\end{array}$ & & & \\
\hline
\end{tabular}

Table 2. Form of technical (technological) causes of violations for overhead lines with a voltage of $6-10 \mathrm{kV}$

\begin{tabular}{|c|c|c|c|}
\hline Reasons for violation & Yes & No & $\begin{array}{c}\text { Quantity } \\
\text { pes. }\end{array}$ \\
\hline \multicolumn{4}{|l|}{$\begin{array}{c}\text { Violation of the structure of the } \\
\text { material of the installation, its part } \\
\text { or assembly }\end{array}$} \\
\hline \multicolumn{4}{|l|}{ Violation of welding, soldering } \\
\hline \multicolumn{4}{|l|}{ Loss of mechanical connection } \\
\hline \multicolumn{4}{|l|}{ Corrosive wear } \\
\hline \multicolumn{4}{|l|}{$\begin{array}{c}\text { Thermal damage overheating, } \\
\text { burnout }\end{array}$} \\
\hline \multicolumn{4}{|l|}{ Electric arc damage } \\
\hline \multicolumn{4}{|l|}{ Loss of electrical contact } \\
\hline \multicolumn{4}{|l|}{ Mechanical destruction } \\
\hline No reasons identified & & & \\
\hline
\end{tabular}


Table 3. Form of technical (technological) causes of violations for transformer substations with a voltage of $6-10 \mathrm{kV}$

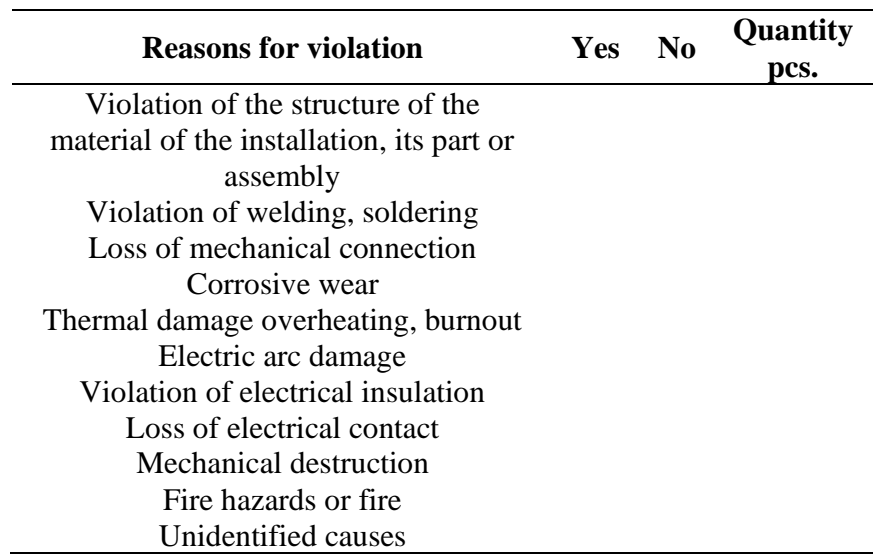

3. Taking into account the specifics of the work of the reliability and safety service, as well as their job responsibilities, it is proposed to analyze and process information with the subsequent presentation of the results and proposals to the relevant services, the reliability and safety service.

4. Results of data processing with the establishment of a quantitative assessment of the reliability indicators of $6-10 \mathrm{kV}$ distribution networks in Dushanbe, taking into account the main and additional factors in the form of tabular and graphical forms.

5. The following should be taken as the initial data for processing and analyzing information:

- Type of consumers;

- Damage time;

- Causes of damage;

- Scheme of the damaged network section;

- Ambient temperature at the time of emergency shutdown;

- The number of household consumers.

6. Output results, which will be used to evaluate reliability indicators:

- Recovery time;
- The flow of failure;

- Undersupply of electricity.

To determine the reliability indicators of $6-10 \mathrm{kV}$ electrical distribution network elements in Dushanbe, it is necessary to propose a mathematical model that allows assessing the state of the $6-10 \mathrm{kV}$ distribution network elements in Dushanbe by such indicators as: flow (frequency) of failure and shortage of electricity. For the initial data, the number of emergency outages for the considered period of time is taken with their distribution due to damage reasons, processed using the methodology developed by us.

The proposed mathematical model of indicators of reliability of elements of distribution electrical networks 6-10 $\mathrm{kV}$ in Dushanbe should allow assessing these indicators. According to the developed methodology for collecting, processing and analyzing information for 2019, the state of the elements of distribution electrical networks $6-10 \mathrm{kV}$ in Dushanbe was analyzed. The analysis results are presented in Tables 4-6.

From the data presented in Table 6 , it can be seen that for 2019 the reliability indicator - the flow of failures and the efficiency of 6-10 kV electrical distribution networks in Dushanbe exceed the permissible values.

Based on the data of the dispatch service and the labor protection service and the reliability of power supply of JSC "City Electric Network Dushanbe" for 2015-2019 using the methodology developed by us for collecting, processing and analyzing information, emergency shutdowns due to damage were analyzed. According to the analysis of emergency shutdowns due to damage causes, factors have been identified that have the greatest impact on the number of stable emergency shutdowns of certain elements of $6-10 \mathrm{kV}$ distribution electrical networks in Dushanbe.

In order to quantitatively assess the reliability of the elements of 6-10 kV electrical distribution networks in Dushanbe, the following indicators were calculated: the flow of failures and undersupply of electricity. The performed analysis showed that in the operating 6-10 kV electrical distribution network in Dushanbe, the undersupply of electricity exceeds the maximum permissible value equal to $10 \%$.

Table 4. Initial data on the regional electric network for the period under review

\begin{tabular}{|c|c|c|c|c|c|}
\hline $\begin{array}{l}\text { Initial data on district power grids } \\
\text { for the period under review }\end{array}$ & $\begin{array}{c}\text { CL, } \\
\text { length, } \\
\text { km }\end{array}$ & $\begin{array}{l}\text { OHL, } \\
\text { length, } \mathbf{k m}\end{array}$ & $\begin{array}{c}\text { TS, } \\
\text { quantity, } \\
\text { pcs }\end{array}$ & $\begin{array}{l}\text { Recovery } \\
\text { time, h }\end{array}$ & $\begin{array}{l}\text { Consumption by the city population } \\
\text { for the period under review } \\
\text { million } \mathrm{kWh}\end{array}$ \\
\hline Somoni & 224 & 45 & 355 & 441 & \\
\hline Shokhmansur & 181 & 62 & 351 & 500 & \\
\hline Firdavsi & 252 & 110 & 301 & 596 & \\
\hline Sino & 373 & 119 & 607 & 1509 & \\
\hline Total & 1030 & 336 & 1614 & 3046 & 1553 \\
\hline
\end{tabular}

Table 5. Emergency shutdowns for district power grids for the period under review

\begin{tabular}{cccc}
\hline Initial data on district power grids for the period under review & $\begin{array}{c}\text { CL } \\
\text { (1/year) } \mathbf{1 0 0} \mathbf{~ k m}\end{array}$ & $\begin{array}{c}\text { Overhead lines } \\
\text { (1/year) } \mathbf{1 0 0} \mathbf{~ k m}\end{array}$ & $\begin{array}{c}\text { TS } \\
(\mathbf{1} / \mathbf{y e a r}) \mathbf{1 0 0} \mathbf{~ p c s .}\end{array}$ \\
\hline Somoni & 170 & 51 & 50 \\
Shokhmansur & 162 & 53 & 42 \\
Firdavsi & 204 & 31 & 67 \\
Sino & 532 & 92 & 163 \\
Total & 1068 & 227 & 322 \\
\hline
\end{tabular}


Table 6. Quantitative assessment of the reliability indicators of 6-10 kV distribution electric networks (flow of failures and shortage of electricity)

\begin{tabular}{cccccc}
\hline $\begin{array}{c}\text { Quantitative } \\
\text { assessment of the } \\
\text { reliability indicators of } \\
\mathbf{6 - 1 0 ~ k V ~ e l e c t r i c a l ~} \\
\text { distribution networks } \\
\text { (flow of failures and } \\
\text { shortage of electricity) }\end{array}$ & $\begin{array}{c}\text { CL, failure } \\
\text { flow } \\
\text { (failure rate) }\end{array}$ & $\begin{array}{c}\text { Overhead line, } \\
\text { flow of } \\
\text { failures } \\
\text { failure rate) }\end{array}$ & $\begin{array}{c}\text { TS, flow of } \\
\text { failures } \\
\text { (failure rate) }\end{array}$ & $\begin{array}{c}\text { Undersupply of } \\
\text { electricity } \\
\text { million kWh }\end{array}$ & $\begin{array}{c}\text { Undersupply of } \\
\text { electricity } \\
\text { \% }\end{array}$ \\
\hline Somoni & 0.76 & 1.15 & 0.14 & 53.35 & 3.44 \\
Shokhmansur & 0.89 & 0.85 & 0.12 & 55.14 & 3.55 \\
Firdavsi & 0.81 & 0.28 & 0.22 & 46.22 & 2.98 \\
Sino & 1.42 & 0.77 & 0.27 & 220.07 & 22.17 \\
Total & 1.04 & 0.68 & 0.20 & 344.14 & 2.16 \\
\hline
\end{tabular}

\section{THE THEORETICAL PART OF THE RESEARCH}

Thus, when developing a methodology for assessing the state of the elements of the $6-10 \mathrm{kV}$ distribution network in Dushanbe, which allows assessing the degree of reliability indicators of the $6-10 \mathrm{kV}$ distribution network, it is necessary to take into account such factors as: increased power consumption [12-15] and climatic and meteorological conditions of the area.

Let us express the degree of reliability of the $6-10 \mathrm{kV}$ distribution network through the undersupply of electricity in relative units:

$$
\Delta W^{*}=W^{*} \cdot \omega^{*} \cdot\left(\frac{t_{\text {recov. }}}{T_{\text {year }}}\right)
$$

where,

$W^{*}$ - relative power consumption;

$\omega^{*}$ - Relative flow of failures; $\mathrm{h}$;

$t_{\text {recov. }}$ - Recovery time for damaged electrical equipment,

$T_{\text {year }}$ - Annual time reserve, 8760 hours.

In turn, the relative flow of failures $-\omega^{*}$ will be determined by the proposed method of collecting, analyzing and processing information on the operating elements of the 6-10 $\mathrm{kV}$ distribution network in Dushanbe using this formula [12, $14]$.

$$
\omega^{*}(t)=\frac{n(t, \Delta t)}{N(0) \cdot \Delta t}
$$

where, $n(t, \Delta t)$ - the number of elements that failed in the time interval from $t$ before $t+\Delta t$

To assess the impact of internal and external factors on the reliability indicators of the $6-10 \mathrm{kV}$ distribution network in Dushanbe, we introduce the following parameters: relative power consumption - $W^{*}$ ambient temperature coefficient ( $\alpha$ ambient temperature coefficient $)$ [15].

These parameters make it possible to take into account the influence of the above factors on the reliability indicators of the $6-10 \mathrm{kV}$ distribution network in the conditions of Dushanbe.

Let's represent these parameters in the form of the following expressions:

- Internal factor:

$$
W^{*}=\frac{W_{\text {acting }}}{W_{\text {recom }}}
$$

where,

$W_{\text {acting }}$ - the values of the current power consumption in the sections with the worst indicators of the reliability of the distribution network 6-10 kV, $\mathrm{kWh}$;

$W_{\text {recom. }}=P_{\text {allowed }} \cdot t_{\text {t.per day }}$ - recommended value of power consumption during the month, $\mathrm{kWh}$;

$P_{\text {allowed }}$ - permitted power provided by the power supply organization $(4-5 \mathrm{~kW})$.

To assess the influence of an external factor, it was proposed - $\left(\alpha_{\text {ambient temperature coefficient }}\right)$ in relative units [15] i.e.,

$$
\begin{aligned}
& \alpha_{\text {ambient temperature coefficient. }}^{*} \\
& =\frac{\left(t_{t_{\text {amb.temp.at the poi.of loc. }}}+t_{\text {temp.diff. }}\right)}{\left(t_{\text {zero poi.temp. }}+t_{\text {add.temp. }}\right)}
\end{aligned}
$$

where,

$t_{\text {amb.temp.at the poi.of loc. }}$ - ambient temperature at the point of location of the distribution network element $6-10 \mathrm{kV},{ }^{\circ} \mathrm{C}$;

$t_{\text {temp.diff. }}$ - Temperature between the point at sea level and the point where the consumer is located above sea level, ${ }^{\circ} \mathrm{C}$;

$t_{\text {zero poi.temp. }}$ - Average monthly ambient temperature at a point at sea level, ${ }^{\circ} \mathrm{C}$;

$t_{\text {add.temp. }}$ - Additional temperature, ${ }^{\circ} \mathrm{C}$.

Let us further consider the presentation of the results of assessing the state of $6-10 \mathrm{kV}$ distribution network elements in terms of reliability indicators using Eq. (1) and factors affecting these indicators (3) and (4).

The resulting equations (1) allow us to assess the state of the elements of the 6-10 kV distribution network in Dushanbe by such an indicator as undersupply of electricity, for taking into account the influence of external and internal factors leading to a violation of such an indicator as - the flow of refusal is proposed to use expressions $(3,4)$. Since the reliability indicator - the flow of failure shows the degree of technical condition of the $6-10 \mathrm{kV}$ distribution network elements in Dushanbe; this reliability indicator is strongly influenced by those factors that were noted above.

According to the document RD 34.20.801-90 in force in the Republic of Tajikistan Instructions for the investigation and recording of technological violations in the operation of power plants, networks and energy systems, all damages are subdivided into: 
(1) Technical (technological);

(2) Organizational.

Consequently, as it was said, the degree of technical condition of the elements of the $6-10 \mathrm{kV}$ distribution network is characterized by such an indicator as - the flow of failure, which in turn depends on external and internal factors. We represent this dependence through the following expression.

$$
\omega^{*}=f\left(W^{*}+\alpha_{\text {ambient temperature coefficient }}^{*}\right),
$$

As can be seen from expressions (5), the reliability indicator of the $6-10 \mathrm{kV}$ distribution network is that the failure flow is directly dependent on power consumption and climatic and meteorological conditions expressed through the coefficient characterizing the terrain conditions.

With a decrease in the ambient air temperature, power consumption increases, this is mainly affected by the absence of other energy sources, and in order to maintain the optimal temperature in the premises, determined, it is necessary to connect many electric heaters. The dependence of power consumption on the climatic and meteorological conditions of the area expressed through the coefficient characterizing the conditions of the area (4) can be represented as the following expressions.

$$
W^{*}=f\left(1-\alpha_{\text {ambient temperature coefficient } .}^{*}\right),
$$

As can be seen from expressions (6), with a decrease in the ambient temperature at the point of location of the object, the resulting coefficient characterizing the conditions of the area decreases, thereby increasing power consumption, while on summer days at high temperatures the opposite process is observed.

The derived Eq. (1), and Eqns. (3)-(6) allowing to take into account external and internal factors made it possible to propose a method for assessing the state of the elements of the $6-10 \mathrm{kV}$ distribution network in Dushanbe. The use of which allows assessing the degree of reliability and efficiency indicators of the distribution network by such a reliability indicator as undersupply of electricity.

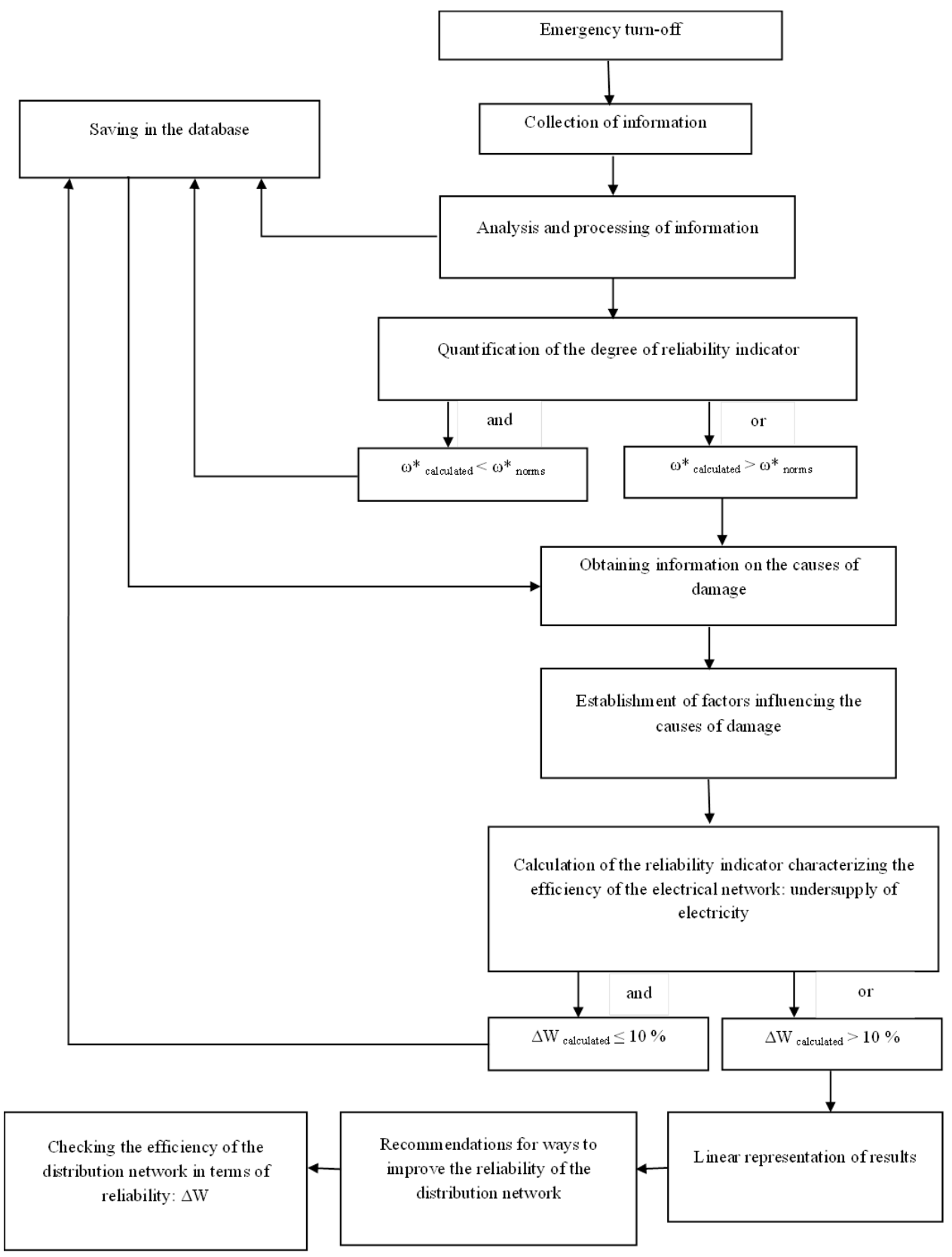

Figure 1. Hierarchy of the method of monitoring the state of the elements of the $6-10 \mathrm{kV}$ distribution network in Dushanbe 


\section{RESULTS OF RESEARCH AND DISCUSSION}

To control the assessment of the state of the $6-10 \mathrm{kV}$ distribution network elements in Dushanbe on the basis of the proposed methods - collection, analysis and processing of information [15] in order to identify factors affecting the degree of reliability indicators of the $6-10 \mathrm{kV}$ distribution network and the method for assessing the state of the 6-10 distribution network elements In the city of Dushanbe, a method for monitoring the technical (technological) conditions of the network under consideration is proposed on the basis of the proposed method.

The method of monitoring the state of the elements of the 6-10 kV distribution network in Dushanbe is presented in the form of a hierarchy (see Figure 1) of the sequence of tasks with a description of all processes in the course of: collection, analysis, processing, storage, comparison, identification and establishment of factors affecting causes of damage, determination (calculated) by the proposed method of the quantitative component of the reliability indicator - the flow of failure and efficiency of the $6-10 \mathrm{kV}$ distribution network in terms of reliability - undersupply of electricity, presenting the results in the form of linear dependence and equations describing these dependences, recommendations for improving the reliability of the distribution $6-10 \mathrm{kV}$ networks in Dushanbe and checking the efficiency of the distribution network, in terms of reliability: $\Delta \mathrm{W}$.

As seen from Figure 1 at all stages of control are described the sequence of tasks in order to propose a way to improve the reliability of the distribution network $6-10 \mathrm{kV}$ in Dushanbe.

Conventionally, this hierarchy can be divided into four stages:

1. Collection, processing and analysis of the information received, this item is implemented according to the proposed methodology for collecting, processing and analyzing information;

2. A quantitative assessment of the reliability indicators of 6-10 kV distribution electrical networks (the flow of failures and undersupply of electricity), this point is made according to the proposed methodology for collecting, processing and analyzing information using the information obtained on the basis of the submitted data of the operational field team;

3. Identification of factors affecting the flow of failures and undersupply of electricity, according to the developed methodology and mathematical model, this item should be implemented according to the processed data and determined using Eq. (1), and Eqns. (2)-(7);

4. Recommendations for improving the reliability of the 6 $10 \mathrm{kV}$ distribution network and checking the efficiency of the distribution network in terms of reliability: $\Delta \mathrm{W}$. The proposed outline of the recommendation is based on the guidance document.

\section{CONCLUSIONS}

1. The analysis of the state of elements of $6-10 \mathrm{kV}$ electrical distribution networks in Dushanbe has been carried out, which showed that the reliability and efficiency indicators of the considered electrical networks exceeded the permissible $10 \%$ values.

2. On the basis of the identified factors affecting the reliability indicators of the elements of $6-10 \mathrm{kV}$ electrical distribution networks in Dushanbe, a mathematical model for determining the state of the elements of $6-10 \mathrm{kV}$ electrical distribution networks in Dushanbe is proposed.

3. An algorithm for monitoring the state of elements of 6 $10 \mathrm{kV}$ electrical distribution networks in Dushanbe is proposed, on the basis of which it is proposed to form a plan to improve the reliability of $6-10 \mathrm{kV}$ electrical distribution networks in Dushanbe and assess the efficiency of 6-10 kV distribution electrical networks in terms of undersupply of electricity $-\Delta \mathrm{W}$

\section{REFERENCES}

[1] Grishkevich A. (2019). Simulation models for assessment of structural reliability indicators distribution for power supply systems. 2019 Applications of Electromagnetics in Modern Engineering and Medicine (PTZE), Janow Podlaski, Poland, pp. 52-55. https://doi.org/10.23919/PTZE.2019.8781736

[2] Blazakis, K.V., Kapetanakis, T.N., Stavrakakis, G.S. (2020). Effective electricity theft detection in power distribution grids using an adaptive neuro fuzzy inference system. Energies, 13(12): 3110. https://doi.org/10.3390/en13123110

[3] Ray, S., Bhattacharjee, S., Bhattacharya, A. (2018). Optimal allocation of remote control switches in radial distribution network for reliability improvement. Ain Shams Engineering Journal, 9(3): 403-414. https://doi.org/10.1016/j.asej.2016.01.001

[4] He, L., Zhang, X.D. (2016). Fuzzy reliability analysis using cellular automata for network systems. Information Sciences, 348: 322-336. https://doi.org/10.1016/j.ins.2016.01.102

[5] Čepin, M. (2011). Assessment of Power System Reliability: Methods and Applications. 2011th Edition, Kindle Edition, p321.

[6] Issi, F., Kaplan, O. (2018). The determination of load profiles and power consumptions of home appliances. Energies, 11(3): https://doi.org/10.3390/en11030607

[7] Angrisani, L., Bonavolontà, F., Liccardo, A., Moriello, R.S.L., Serino, F. (2018). Smart power meters in augmented reality environment for electricity consumption awareness. Energies, 11(9): 2303; https://doi.org/10.3390/en11092303

[8] Yan, K., Wang, X.D., Du, Y., Jin, N., Huang, H.C., Zhou, H.X. (2018). Multi-step short-term power consumption forecasting with a hybrid deep learning strategy. Energies, $11(11)$ : 3089. https://doi.org/10.3390/en11113089

[9] Vojtovic, S., Stundziene, A., Kontautiene, R. (2018). The impact of socio-economic indicators on sustainable consumption of domestic electricity in Lithuania. Sustainability, $10(2)$ : 162. https://doi.org/10.3390/su10020162

[10] Ziel, F. (2020). Load nowcasting: predicting actuals with limited data. Energies, 13(6): 1443. https://doi.org/10.3390/en13061443

[11] Naz, A., Javed, M.U., Javaid, N., Saba, T., Alhussein, M., Aurangzeb, K. (2019). Short-term electric load and price forecasting using enhanced extreme learning machine optimization in smart grids. Energies, 12(5): 866. https://doi.org/10.3390/en12050866

[12] To, W.M., Lee, P.K.C., Lai, T.M. (2017). Modeling of 
monthly residential and commercial electricity consumption using nonlinear seasonal models-The case of Hong Kong. Energies, 10(7): 885. https://doi.org/10.3390/en10070885

[13] Sidorov A.I., Tavarov, S. (2021). Enhancing reliability of electricity supply of city electric networks cities of Dushanbe. Bulletin of Electrical Engineering and Informatics, $10(1)$ : 46-54. https://doi.org/10.11591/eei.v10i1.2114

[14] Sidorov A.I., Tavarov S.S. (2020). Method for forecasting electric consumption for household users in the conditions of the Republic of Tajikistan. International Journal of Sustainable Development and Planning, 15(4): 569-574. https://doi.org/10.18280/ijsdp.150417

[15] Tavarov, S.S., Sidorov, A.I., Kalegina, Y.V. (2020). Model and algorithm of electricity consumption management for household consumers in the republic of Tajikistan. Mathematical Modelling of Engineering Problems, 7(4): 520-526. https://doi.org/10.18280/mmep.070403 